ks. Józef Stala

\title{
Konferencja naukowa Wkład księdza Walentego Gadowskiego (1861-1956) w rozwój katechetyki (Tarnów, 15 listopada 2006)
}

„Młodzież chętnie czytała książki i to dobrze o niej świadczyło, zwłaszcza że władze szkolne zabraniały wówczas sportów i zabaw ruchowych na świeżym powietrzu. Kto czytał i uczył się, ten się nie włóczył i nie lampartował” (ks. Walenty Gadowski, Wspomnienia katechety).

14 maja 1956 roku w Bochni w wieku 95 lat zmarł ks. Walenty Gadowski, kapłan diecezji tarnowskiej, katecheta, wykładowca i teoretyk katechetyki, wspóltwórca psychologicznej metody w nauczaniu religii, redaktor „Dwutygodnika Katechetycznego”. W 50. rocznicę śmierci ks. Walentego Gadowskiego w tarnowskim środowisku naukowym 15 listopada 2006 roku w auli Wyższego Seminarium Duchownego przy ul. Piłsudskiego 6 w Tarnowie odbyła się konferencja naukowa Wkład ks. Walentego Gadowskiego (1861-1956) w rozwój 
katechetyki zorganizowana przez Polskie Towarzystwo Teologiczne Oddział w Tarnowie. Współorganizatorem była Papieska Akademia Teologiczna w Krakowie Wydział Teologiczny Sekcja w Tarnowie Katedra Nauk PedagogicznoKatechetycznych oraz Wyższe Seminarium Duchowne w Tarnowie.

Słowo powitania do licznie zgromadzonych uczestników konferencji naukowej skierował ks. dr Wiesław Lechowicz, rektor Wyższego Seminarium Duchownego w Tarnowie. Konferencja została przeprowadzona w dwóch sesjach, a referaty wygłosili naukowcy z trzech ośrodków naukowych w Polsce: Krakowa, Warszawy i Tarnowa. Prowadzenie pierwszej sesji konferencji powierzono ks. drowi hab. Adamowi Solakowi z Sekcji w Tarnowie Wydziału Teologicznego Papieskiej Akademii Teologicznej w Krakowie, a swoje referaty zaprezentowali w niej ks. dr hab. Józef Stala z Sekcji w Tarnowie Wydziału Teologicznego Papieskiej Akademii Teologicznej w Krakowie, który przybliżył sylwetkę ks. Walentego Gadowskiego, a następnie ks. prof. dr hab. Władysław Kubik z Wyższej Szkoły Filozoficzno-Pedagogicznej Ignatianum w Krakowie, który mówił nt. Wkład ks. Walentego Gadowskiego w rozwój myśli dydaktycznej w katechetyce na przetomie XIX $i$ XX wieku (kontekst historyczny i społeczno-polityczny). Z kolei ks. dr hab. Tadeusz Panuś, profesor Papieskiej Akademii Teologicznej w Krakowie, przedstawił Wkład ks. Walentego Gadowskiego w rozwój katechetyki europejskiej (kongresy katechetyczne). Po przerwie prowadzenie obrad drugiej sesji objął ks. dr hab. Józef Stala. Swoje referaty wygłosili: ks. prof. dr hab. Kazimierz Misiaszek z Uniwersytetu Kardynała Stefana Wyszyńskiego w Warszawie nt. Katecheta w świetle pism ks. Walentego Gadowskiego, dr Elżbieta Osewska z tej samej uczelni nt. Środki dydaktyczne w ujęciu ks. Walentego Gadowskiego, z kolei ks. dr Bogusław Połeć reprezentujący Sekcję w Tarnowie Wydziału Teologicznego Papieskiej Akademii Teologicznej w Krakowie przedstawił ks. Walentego Gadowskiego jako twórcę ruchu katechetycznego, a ks. dr hab. Adam Solak - Walory pamiętnika ks. Walentego Gadowskiego. Sugestie dla czytelnika. Zamknięcia i podsumowania konferencji naukowej dokonał ks. dr hab. Antoni Żurek, dziekan Sekcji w Tarnowie Wydziału Teologicznego Papieskiej Akademii Teologicznej w Krakowie.

Na podstawie przedstawionych wykładów można stwierdzić, iż ks. Gadowski był nieprzeciętnym nauczycielem, bardzo wyrazistym, wzbudzającym szacunek i podziw, co współczesnym nauczycielom powinno uświadamiać wielkość nauczycielskiego powołania. Wiąże się ono nie tylko z zaszczytem i wyróżnieniem, ale także z ogromnym trudem i odpowiedzialnością. Ks. Gadowski zrobił bardzo wiele dla spraw katechetycznych zarówno w Polsce, jak i w Europie. Jego wielkość tkwi w pionierskim wytyczaniu katechetyce nowych dróg. Wydaje się, że mimo 50 lat, które upłynęły od śmierci ks. Walen- 
tego Gadowskiego, wiele jego propozycji wciąż może stanowić inspirację do ciekawych i owocnych poszukiwań w dziedzinie pedagogiki i katechetyki.

W publikacji pokonferencyjnej w pierwszej części Ks. Walenty Gadowski jako twórca nowych myśli w katechetyce znalazły się wymienione referaty poprzedzone słowem bpa Wiktora Skworca, ordynariusza diecezji tarnowskiej, oraz wstępem kierownika Oddziału w Tarnowie Polskiego Towarzystwa Teologicznego ks. dra hab. Janusza Królikowskiego. W drugiej części książki: Ks. Walenty Gadowski jako propagator syntezy pedagogiki tradycyjnej $i$ współczesnej zamieszczono publikowane na przestrzeni kilkudziesięciu lat artykuły dotyczące ks. Walentego Gadowskiego, a więc: ks. Piotra Bednarczyka Ks. Walenty Gadowski w walce o lepsza metodę nauczania religii, ks. Piotra Poręby Naukowe podstawy pedagogiki ks. Walentego Gadowskiego i Ks. Walenty Gadowski - wychowawca dzieci i młodzieży; Działalność ks. Walentego Gadowskiego na polu wychowania, ks. Józefa Stali Pedagogiczne propozycje J. F. Herbarta w refleksji ks. Walentego Gadowskiego oraz Skuteczność wychowawczych oddziaływań rodziców według ks. Walentego Gadowskiego. Recenzje wydawnicze tej publikacji przygotowali: ks. dr hab. Janusz Królikowski (Papieska Akademia Teologiczna w Krakowie Wydział Teologiczny Sekcja w Tarnowie) i ks. dr hab. Marian Zając (Katolicki Uniwersytet Lubelski Jana Pawła II). 